\title{
Sustainability Analysis of Competition in Public Transport Systems: A Comparative Case Study in Hungary and Finland
}

\author{
András Lakatos ${ }^{1 *}$, Péter Mándoki ${ }^{1}$ \\ 1 Department of Transport Technology and Economics, Faculty of Transportation Engineering and Vehicle Engineering, Budapest \\ University of Technology and Economics, H-1111 Budapest, Műegyetem rakpart 3., Hungary \\ * Corresponding author, e-mail: lakatos.andras@mail.bme.hu
}

Received: 09 August 2019, Accepted: 22 March 2019, Published online: 14 April 2020

\begin{abstract}
Ongoing competition between bus and railway systems in European (especially in the middle, south and east part) regional passenger transport is a current problem. Long term sustainability and efficiency in passenger transport requires a balanced transport policy. These subsectors need to be complement each other, not compete. The parallel bus and railway links can result in a competition. This research explores solutions to this issue for long term environmental and economic sustainability optimization. Some of the important factors include the number of inhabitants to be served, public transport availability, and efficiency in time of travel for vehicles and passengers. To ensure long term sustainability of the presented methodology, the effect of interventions was analyzed. The study compares Finland and Hungary in terms of the competition regional railway and bus links.
\end{abstract}

\section{Keywords}

optimization of parallelisms in public transport, regional public transport, quality of public transport

\section{Introduction}

Public transport plays a significant role in people's lives in Hungary, also affecting the national economy. Therefore, its development is essential for long term environmental and economic sustainability. Even though there is constant innovation, thanks to both governmental and EU subsidies, macroscopic traffic organizational tasks remain marginalized, which brings the aforementioned long term economic sustainability into question.

Modal split between transport subsectors was researched by [1], as well as [2, 3], whose investigations concern the comparative analysis of subsectors. In Europe [4-11] investigated this topic. Albert and Tóth [12] researched this topic in a more detailed manner, arriving at an index number that is similar but based on a different approach, while [13] researched the topic from the management's point of view.

The problem can be modelled based on [14], but first of all, it can be said, that these researches can be used as a base to examine different transport modes, but none of them evaluates parallelism in long distance public transport system.

The economically long term sustainable solution would be a market-based, non-state-subsidized passenger transport service. Unfortunately decree regulation (EC) No. 1370/2007 of the European Parliament states that "[...] currently multiple countrywide passenger transport services meet the needs of general economic interest, therefore cannot be operated on a commercial basis". That is the contradiction between long term economic and social sustainability. In this paper, the research hypothesis was to find competition between public transport services and possibly define a quality index that could describe possibilities of intervention, to reach long term sustainability.

\section{Methodology}

Previous researches examined different user and operator-parameters of Budapest-centered parallel long-distance bus and train services, to recognize users' requirements about the quality of the service [15]. This research aimed to analyze this process from the supply side. Firstly, in this article, an objective index was created. The created index evaluates the quality of the competing regional and suburban public transport systems (parallel bus and train links). For this reason, a four-step survey methodology was generated, suitable for the assessment of public transport competition. Albert and Tóth [12] previously introduced an index (called "concurrency-index"), which was capable of analyzing the current situation, while this 
methodology examines parallelism in a different way as the created new index number shows not only the substitutability of transport modes, but also the transport management interventions (Fig. 1) to improve competitiveness of each subsectors.

In the selection, the links chosen had at least one endpoint in a county capital, and each link was shorter than $150 \mathrm{~km}$. This research principally concentrates on travel times, such as [3]. In addition to this, access and egress times of the bus and train stations were incorporated via route planning software (Google Maps). The methodology was generated based on the timetable of the buses and trains, in all of the towns we surveyed. After accessing the bus or train station; in the county capitals or the capital city, we allocated 10 minutes of preparation time for the passengers to attend to their rest stop needs in the station (e.g. buying tickets, locating the platform of the departing bus or train, using the restroom etc.). The travel time between city $i$ and $j$ symbolizes $\left(t_{\text {travel } i, j}\right)$ the total value of elapsed time with transport mode $k$. The sum of running time $\left(t_{\text {running } i, j}\right)$, the access time $\left(t_{\text {access } i, j}\right)$, and the egress time $\left(t_{\text {egress } i, j}\right)$ as Eq. (1) shows.

$t_{\text {travel } i, j, k}=t_{\text {runningi, }, j, k}+t_{\text {access } i, j, k}+t_{\text {egressi, }, k, k}$,

where:

$i$ : origin settlement

$j$ : destination settlement

$k$ : examined transport mode (bus (b) or train (v)).

Hereafter, the notation mentioned above was consistently used. The smaller the travel time value is, the higher the quality of the service is rated. Supply, meaning the number of vehicles available, and their frequency operating the links daily $\left(n_{\text {day } i, j, k}\right)$, the more links or larger frequency exist between the departing station and the destination station, the higher the quality of service is. As the values of travel time should be the lowest possible, index-number for a daily number of links is also introduced, which is counter-proportional with the qualityindex. Therefore, a specific departing index $\left(n_{\text {specifci } i, k, k}\right)$ was also defined, symbolizing the reciprocal value of the number of links per day, as shown in Eq. (2).

$$
n_{\text {specifici }, j, k}=\frac{1}{n_{\text {dayi }, j, k}}
$$

The value of the quality index $\left(q_{i, j, k}\right)$ consists of the specific departing index times the value of the travel time, as seen in Eq. (3).

$q_{i, j, k}=n_{\text {specifici }, j, k} \cdot t_{\text {travel } i, j, k}$

The different transport modes' quality of service is inversely proportional to the value of the quality index mentioned above. Naturally, this value should be weighted, as, during the comparison of the bus and railway links, the number of inhabitants should also be incorporated. It is an important, influential factor because of the higher the number of inhabitants, the higher the demand for quicker connections and more frequent public services will become. In settlements with fewer inhabitants, real demand probably exists only in rush hours. In less frequented periods of the day, fewer departures would be needed here, and so the contradiction between social and economic sustainability is even greater. Because of this, the quality index

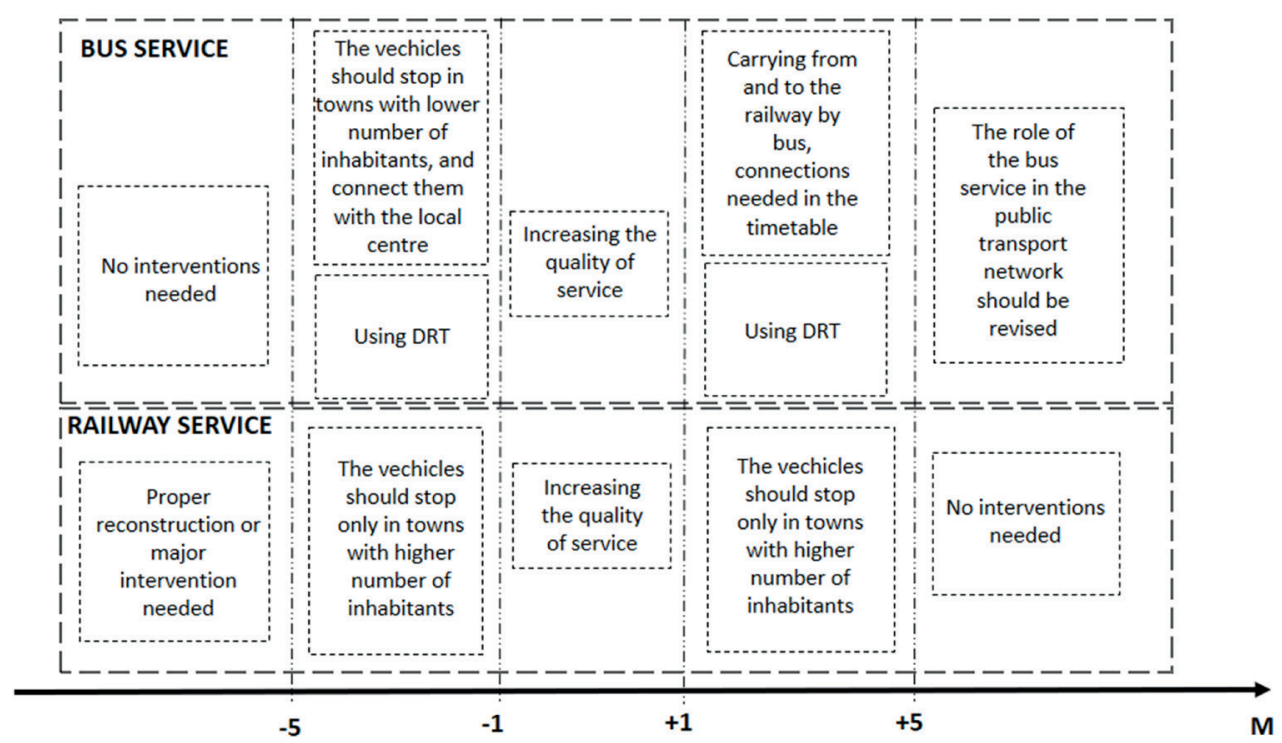

Fig. 1 The examined parallel (regional train and bus) links pictured in map (source: own compilation) 
required to be weighted with the number $\left(p_{j}\right)$, denoting the number of inhabitants in settlements covered by the examined links. It eventuates the quality index multiplicated by the number of inhabitants $\left(Q_{i, j, k}\right)$, based on Eq. (4).

$$
Q_{i, j, k}=q_{i, j, k} \cdot n p_{j}
$$

From the equations - given above - an objective, databased index number can be calculated, which symbolizes the quality of a railway and bus service. These two different transport modes can be compared, and there is room to involve more than two modes of transport. Equation (5) symbolizes the differences $\left(m_{j}\right)$ of the calculated numbers result in the value of the compared services.

$m_{i, j}=Q_{i, j, k=2}-Q_{i, j, k=1}$

Authors have created a quality index number (which is presented in Eq. (6)) to denote the link of transport, which can take five values.

$$
M=\sum_{j=1}^{n} n m_{i, j}
$$

\section{Results}

Based on the values of quality index number, the following interventions are suggested as theoretical results of methodology (Fig. 2).

Experimental results show that a significant difference in service levels of transport modes affects the passengers' modal choice. Therefore, the ratio of 5 considered as a significant difference in perceived service level.

- If $\mathrm{M}<-5$ than the competitiveness of the railway link can only be increased by a larger investment (e.g. introducing electric railways lines, replanning track routes, increasing the speed etc.). If such investment is unreasonable (e.g. the value of social benefits is extremely slight), the bus service should be increased;

- If $-5 \leq \mathrm{M}<-1$ than railway competitiveness can be increased with transport organization tools (e.g. cyclic schedule, stop optimization), besides keeping the explorative role of bus services to small towns (even the DRT);

- If $-1 \leq M \leq 1$ than keeping up the existing parallel bus and railway services, the quality of service should be maintained and the transport system revised (e.g. the different transport modes complementing each other in space and time; to better meet demands);

- If $1<\mathrm{M} \leq 5$ than the bus links should carry to and from the railway links. Besides this, revision of the railway stops is necessary (e.g. creating a direct

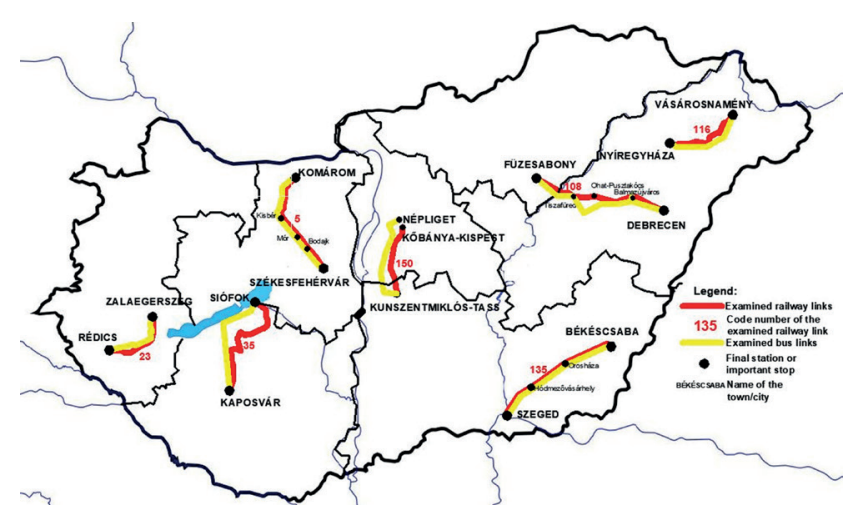

Fig. 2 The proposed interventions gear to the value of the quality index number (source: own compilation)

connection between regional centers and bigger towns without intermediate stops). The closed railway stops - because of the optimization - should be served by demand-responsive bus transport;

- If $M>5$ than the role of the bus service in the public transport network should be revised (e.g. modifying the bus routes; closing bus links; changing the supply etc.).

In the following, we compare the parallel railway and bus links based on the above statements. Though the methodology generates the index numbers - which are suitable for comparing parallel bus and railway links - based on several points of view and variables, the exactness of this value might increase by the survey of further parameters (e.g. the volume of commuters or jobs in a town or township etc.). Furthermore, the methodology does not account for traveling demands. It assumes that the mobility demands are proportional to the number of inhabitants of towns or townships. In some cases (e.g. border towns), it is possible that the low value of the links per day can deform the value of the link-related quality index number. A more detailed revision or correction of these - extremely high values would be suggested.

By comparing seven parallel bus and railway connections in Hungary, as the actual case study, the result can be ranked under four quality index intervals out of 5 , seen in Table 1, which shows, that the value of the quality index (indicated with M) was under -5 in two cases (Kaposvár-Siófok, and Székesfehérvár-Komárom), and resulted in values between -5 and -1 twice (NyíregyházaVásárosnamény and Zalaegerszeg-Rédics). The SzegedBékéscsaba link generated values of about 0 (-0.29), and in the case of Budapest-Kunszentmiklós (2.03) and Debrecen-Füzesabony (4.98) relations, the value of the quality index was between 1 and 5. It should be noted that there were no values above 5 in the scope of our research. 
Table 1 Results from the comparison of the parallel links. (source: own compilation)

\begin{tabular}{lc}
\hline Name of the parallel link & M \\
\hline Kaposvár - Siófok & -19.29 \\
Székesfehérvár - Komárom & -13.71 \\
Nyíregyháza - Vásárosnamény & -1.68 \\
Zalaegerszeg - Rédics & -5.00 \\
Szeged - Békéscsaba & -0.29 \\
Budapest - Kunszentmiklós & 2.03 \\
Debrecen - Füzesabony & 4.97 \\
\hline
\end{tabular}

Value under -5 can be explained three different causes. The calculated values can be influenced decisively by the difference in the number of inhabitants of settlements covered by the railway links, the travel times between the settlements, and by supply per day. In the case of link Kaposvár-Siófok $(M=-19.29)$, out of 22 railway stops (covered by the railway links) only 8 of them serve settlements with a population above 1000 people. Furthermore, it should be noted that some of the areas with stops serve rural areas with a population under 100 people. For long term social and economic sustainability, the bus service should be supported by transport policy. Currently, both services are available, with travel time over 1 hour shorter using a bus for transport. Fig. 3 contains the results in more detail.
Regarding the Székesfehérvár-Komárom link, towns with larger population stand out. The supply per day denotes a significant difference, because while between Székesfehérvár and Mór only four trains operate per day, passengers may utilize 87 bus departures each day, which brings back the question of balance in long term social and economic sustainability. Based on Fig. 2, Fig. 3, and Fig. 4, the competitiveness of railway services can only increase with more significant investments (e.g. replanning the track, increasing the speed etc.). Most likely, the current demand can be served by the bus service more appropriately because of the lower number of stops covering smaller communities.

Furthermore, renovation of the tracks will most likely effect limited social benefits too, due to the low number of commuters. This situation brings into question the legitimacy of railway lines altogether.

The value of the quality index number of link Zalaegerszeg-Rédics is -5 . On our scale, it is placed on the border of value intervals under -5 and between -5 and -1 . Based on Fig. 5, it can be said, that out of the covered 14 settlements, only four stops take place in settlements with a population more than 1000 people. There is a significant difference in supply, and in some cases in the travel time between using trains and bus. For example, between Zalaegerszeg and Bocfölde the travel times have

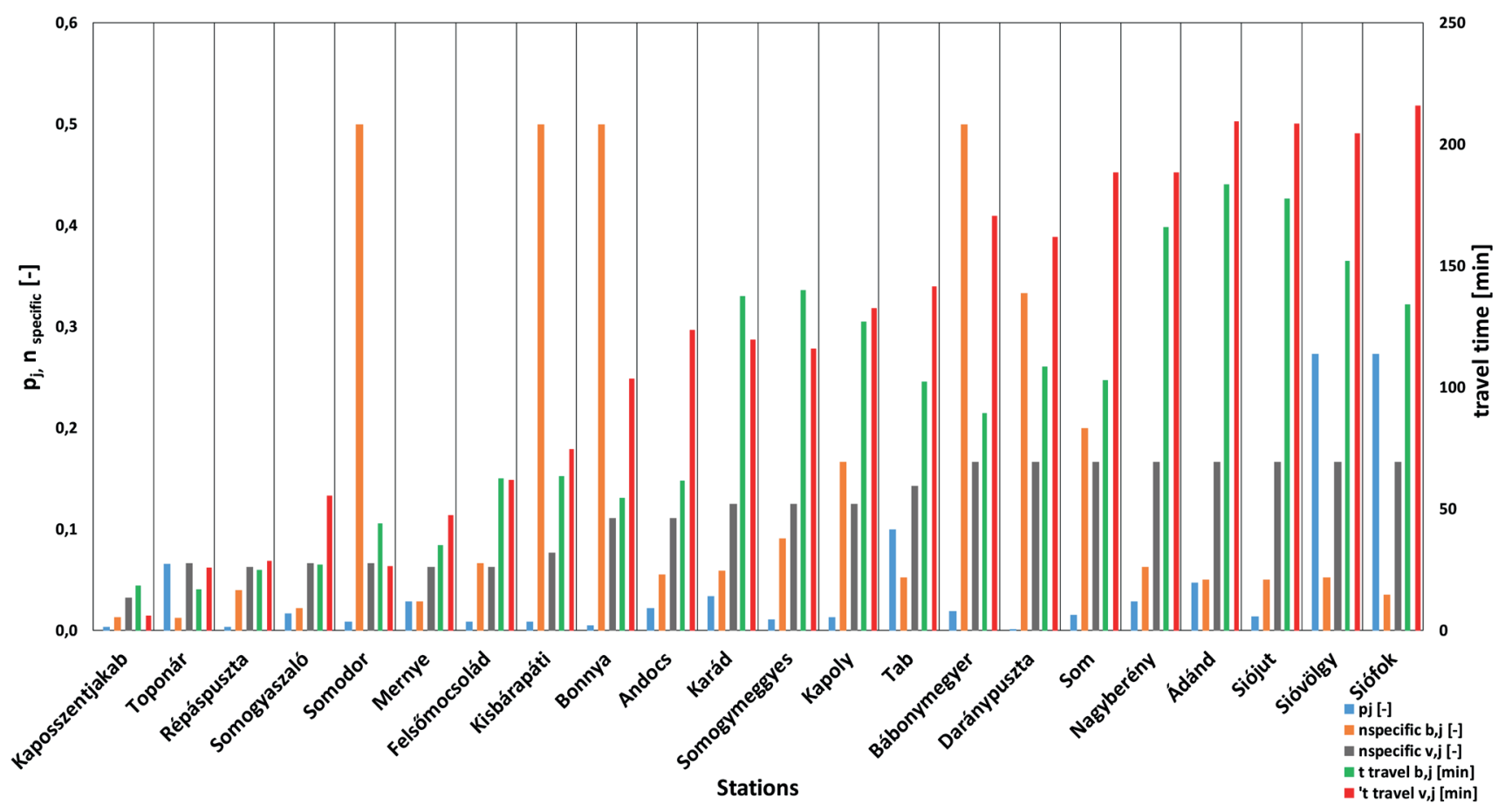

Fig. 3 Calculated values in the link Kaposvár - Siófok (source: own compilation) 


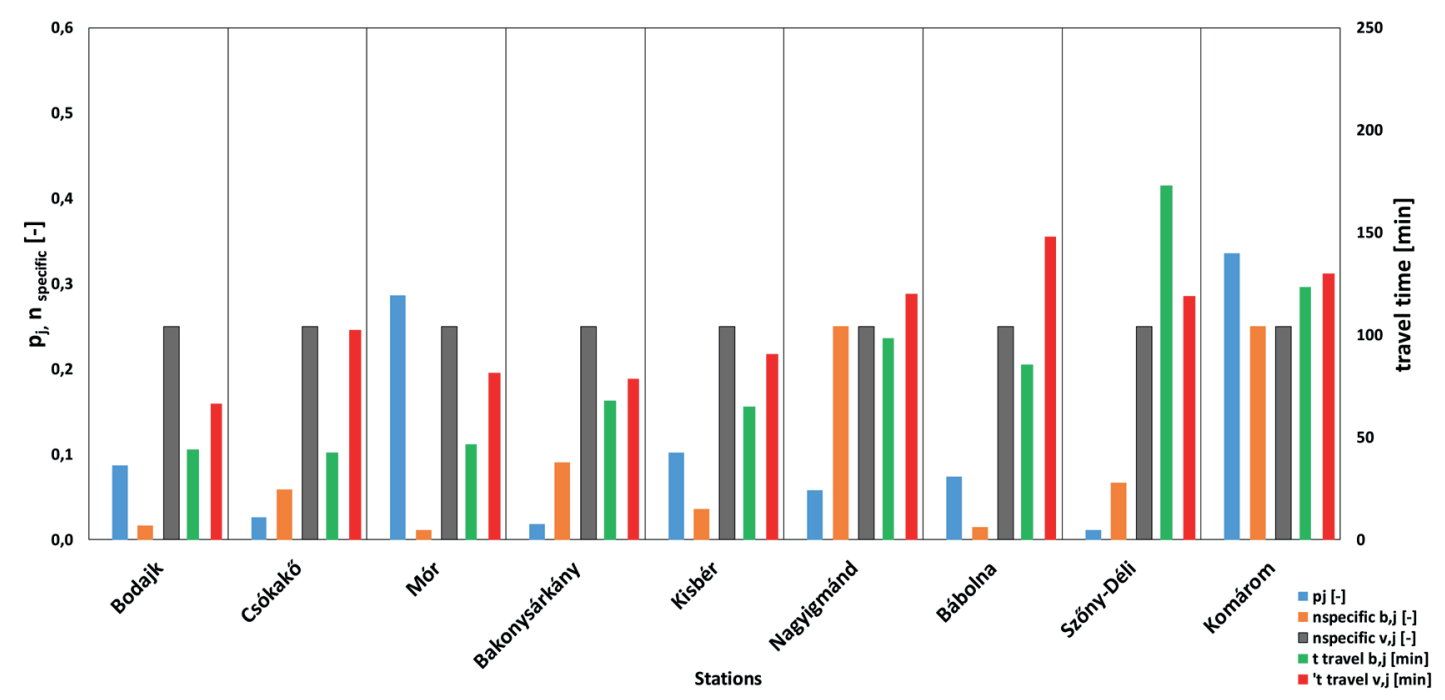

Fig. 4 Calculated values in the link Székesfehérvár-Komárom (source: own compilation)

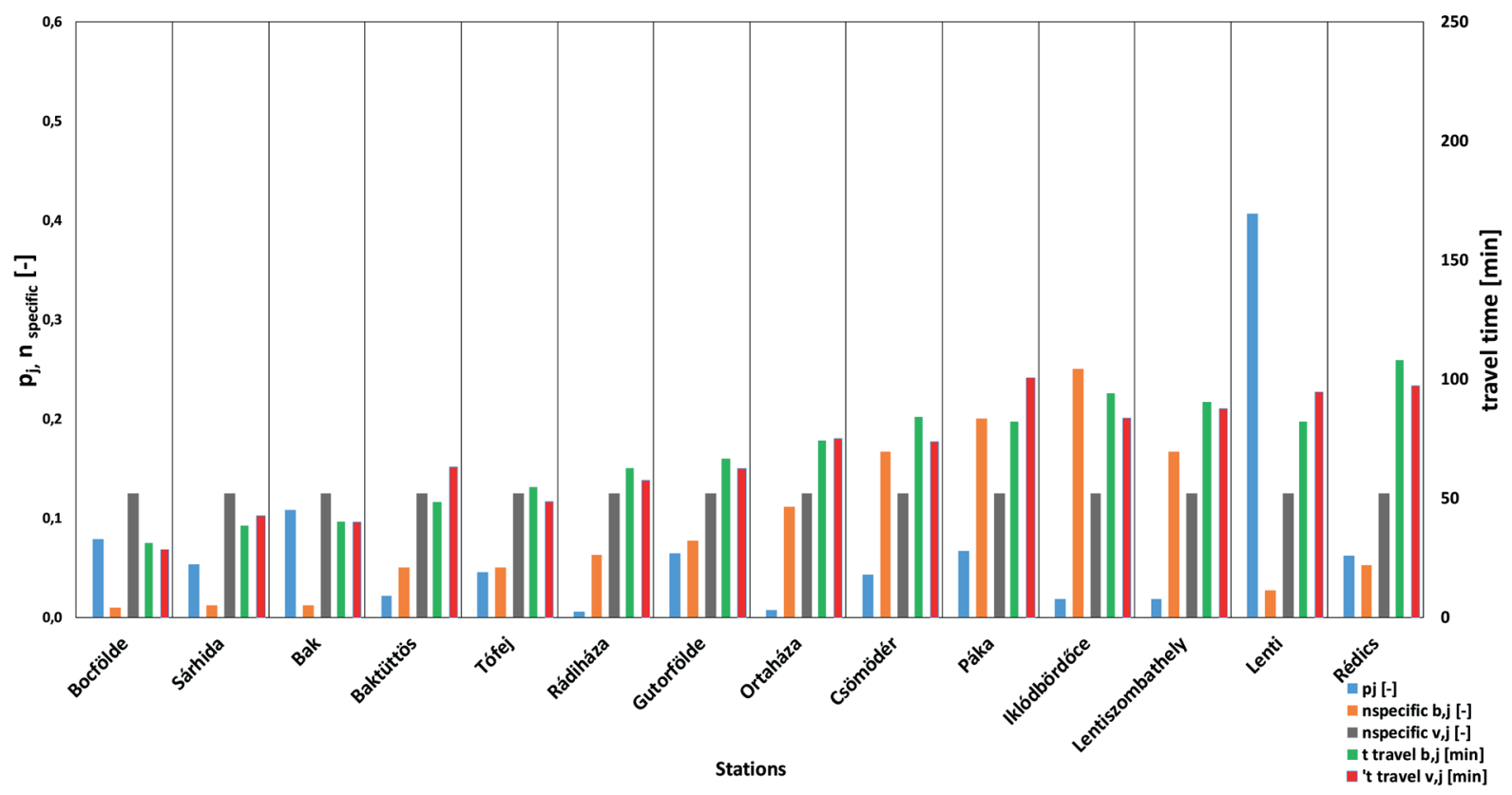

Fig. 5 Calculated values in the link Zalaegerszeg-Rédics (source: own compilation)

approximately the same values (the railway guarantees 2 minutes better access time), but next to 100 bus departures each day only eight trains are departing daily. The same is true for between Sárhida and Bak ( 8 train, 83 bus departures per day).

Furthermore, it is essential to see, that in the case of the communities with a population above 1000 , bus service guarantees the same or much better values of access time, then the railway. In this relation an extremely detailed survey (e.g. cost-benefit examination, passenger interrogation etc.) is necessary to evaluate the expensive renovation of the railway line (e.g. railway line electrification, replanning the track etc.) or the possibility of closure to reach the path of lasting sustainability. The link NyíregyházaVásárosnamény received values of -5 and -1 (Fig. 6), which includes settlements with a higher population than the towns above. Of the 14 towns surveyed only 4 have a population of under 1000 people. Regarding the commuter supply the segments between Nyíregyháza and Oros and between Nyíregyháza and Baktalórántháza have significant value. In the first relation 16 trains and 67 buses departure daily, while in the latter relation the passengers can choose from 16 trains and 63 buses per day.

An analysis of the North Hungarian regional link, significant differences materialize in the values of travel time - aside from supply - for the bus link, which accounts 
for the negative value of the quality index number (e.g. Nyíregyháza to Vaja the travel time can be 44 minutes shorter, from Nyíregyháza to Vásárosnamény 33 minutes shorter by bus than train). Railway stops need to be rationalized in light of population density in the towns covered by the link to reduce travel time values. By optimizing railway stops the values of travel time between cities with higher population can be reduced, thus improving the quality index number. However, this brings about the question of social sustainability and social equity. Furthermore, railway link supplies should be reviewed as well as the introduction of a demand orientated or cyclic timetable. For buses an on-demand responsive transport system might be introduced for villages with fewer inhabitants (e.g. call the bus). By comparing the railway and the bus links' quality between Szeged and Békéscsaba (Fig. 7) the value of the quality index number was calculated between -1 and $1(-0.29)$.

This value of quality index number shows the bus service quality as slightly better. However, the connections between the towns with higher populations (e.g. Orosháza, Hódmezővásárhely, Békéscsaba) should serve an express

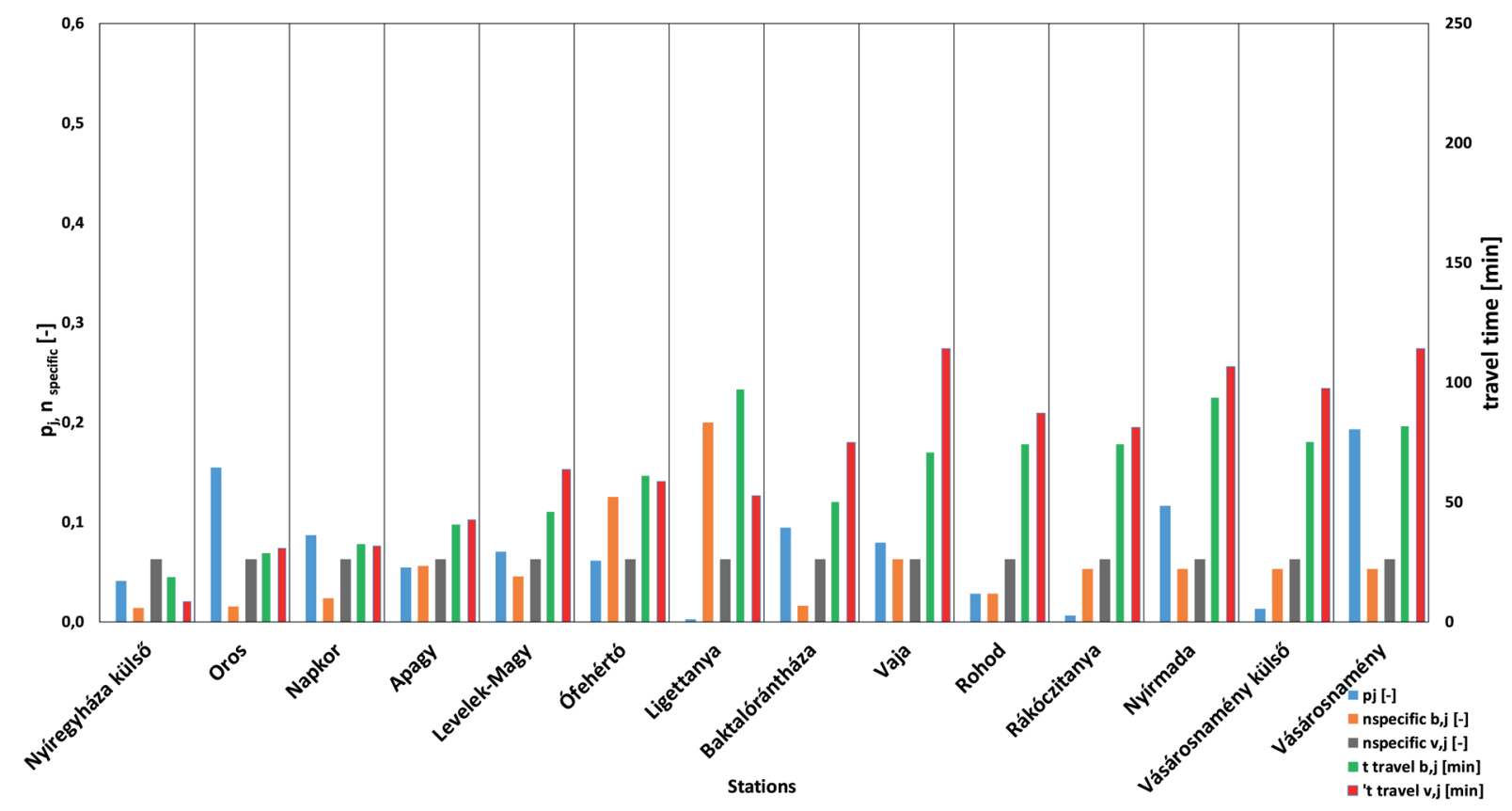

Fig. 6 Calculated values in the link Nyíregyháza-Vásárosnamény (source: own compilation)

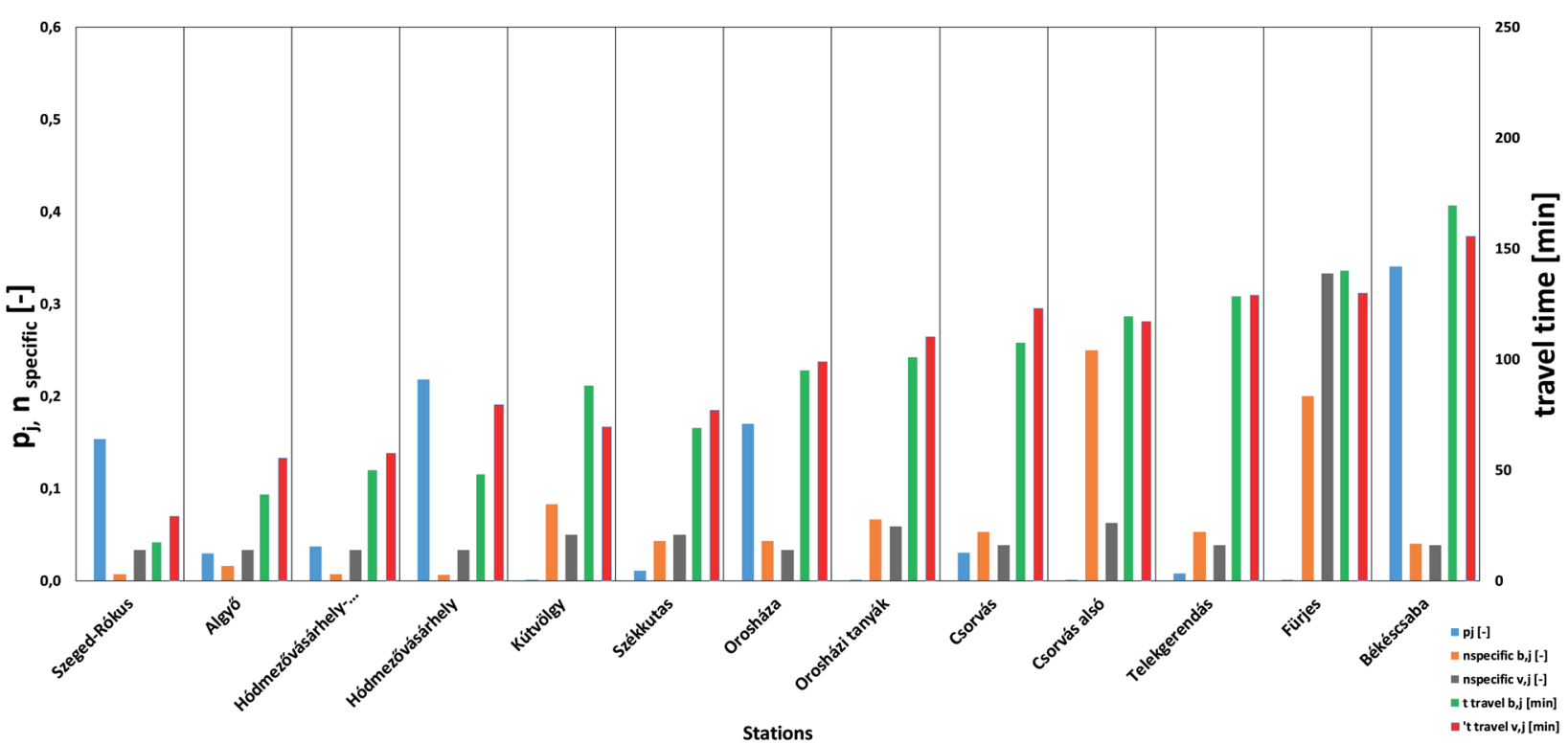

Fig. 7 Calculated values in the link Szeged-Békéscsaba (source: own compilation) 
or stopping railway service because the higher number of inhabitants generates higher travel demand. Traveling from Szeged to Csorvás (and to all intermediate stops) by bus guarantees more favorable values of travel time. By introducing express trains, which have stops only in the main towns (Csorvás, Orosháza, Hódmezővásárhely) the runtime can be reduced significantly, which would, in turn, increase the competitiveness the railway link. Small towns, in the meantime, should continue to be served by bus by increasing the supply. Operating local service trains is also a possible interventional tool, with intermittent stops between the larger cities of Szeged, Orosháza, and Békéscsaba based on values of travel time. Between Szeged and Hódmezővásárhely the bus service guarantees significantly better supply and travel time values than the train, so the competitiveness of the railway service should be increased in relations where the mentioned values are nearly the same, or railway could guarantee better service. The above mentioned local service train system could be a solution to this problem. It is essential to review the bus timetable to serve the smaller towns, townships efficiently - equal distribution of the bus departures in a day - or to introduce demand-responsive transport.

By examining the parallel links between Budapest and Kunszentmiklós-Tass (Fig. 8), it can be seen (value of quality index number 2.03), that the railway service guarantees better values of travel time than the bus between Budapest and Dunavarsány or Délegyháza. But in the cases of Dömsöd and Kiskunlacháza - because of the train station's inconvenient location - the passengers can reach Budapest faster by bus. In case of the latter two towns a bus network needs to be developed, which carries the passengers from or to the train station and serves a cyclic, integrated schedule. Operating passenger trains - which stop between Délegyháza and Budapest at all stations - is also an option worth considering.

The value of the quality index number is quite low, due partially to the lack of infrastructure to carry passengers from or to the end stations and the low value of the supply of the bus service between Budapest and Kunszentmiklós or Tass. Each mode of transport needs to be complementary in time and space to meet the higher traveling demand generated by the high number of inhabitants of the following cities in Fig. 8.

The value of quality index number regarding the link between Debrecen-Füzesabony (Fig. 9) lies on the border of two value-intervals (between 1-5 and above 5). By comparing the bus and railway links between Debrecen and Füzesabony across the flatlands of Hortobágy, it is essential to note that between Debrecen and the bigger towns the bus service delivers significantly better values of travel time, while the supply has the same value for the different transport modes except between Debrecen and Tócóvölgy, Nagyhát, Balmazújváros, and Egyek. The value of a link-related quality number is more significant than 0 , because the bus service between Debrecen and Egyek - which is located on the border of BorsodAbaúj-Zemplén, Jász-Nagykun-Szolnok, and Hajdú-Bihar

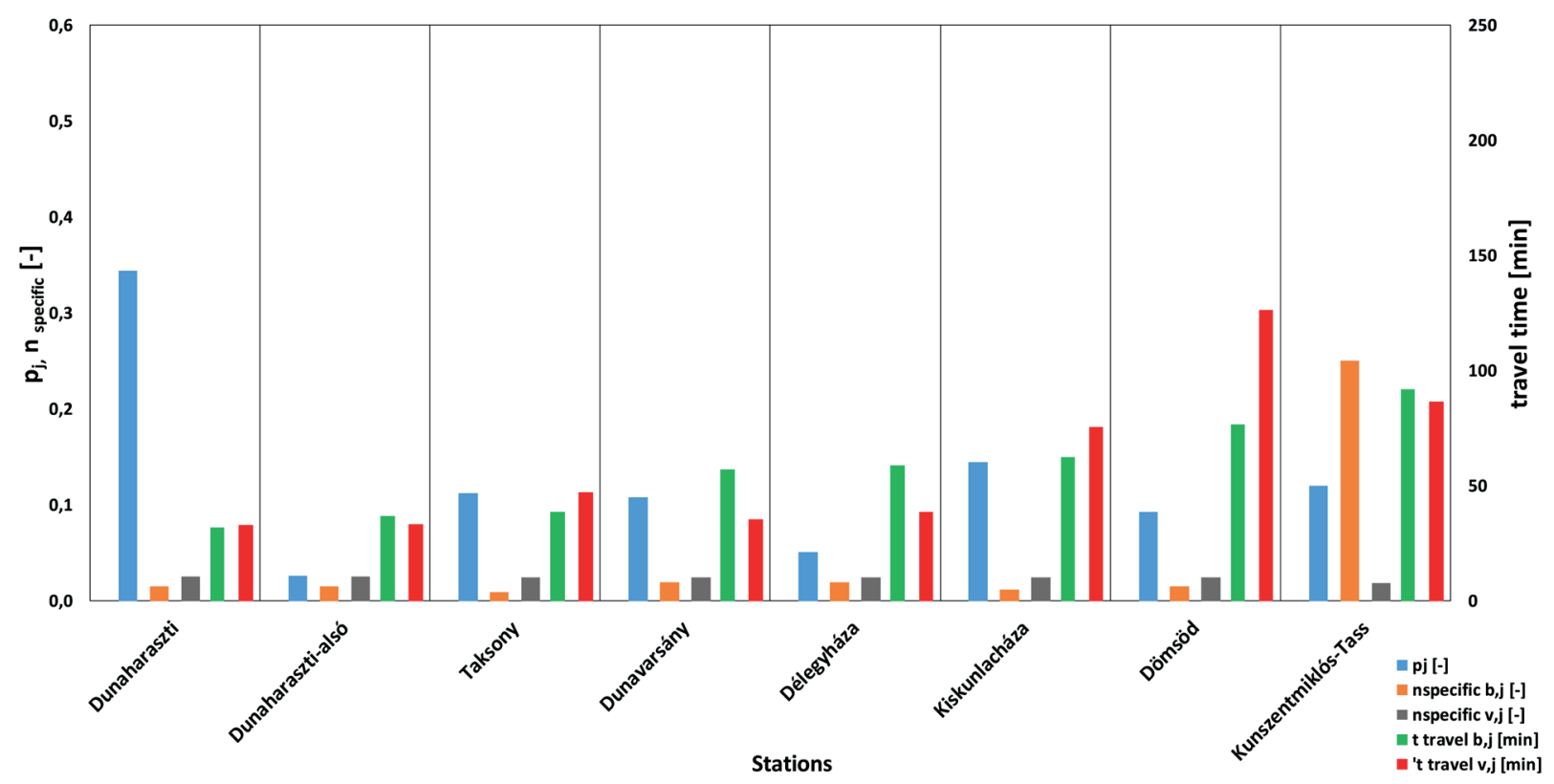

Fig. 8 Calculated values in the link Budapest - Kunszentmiklós-Tass (source: own compilation) 


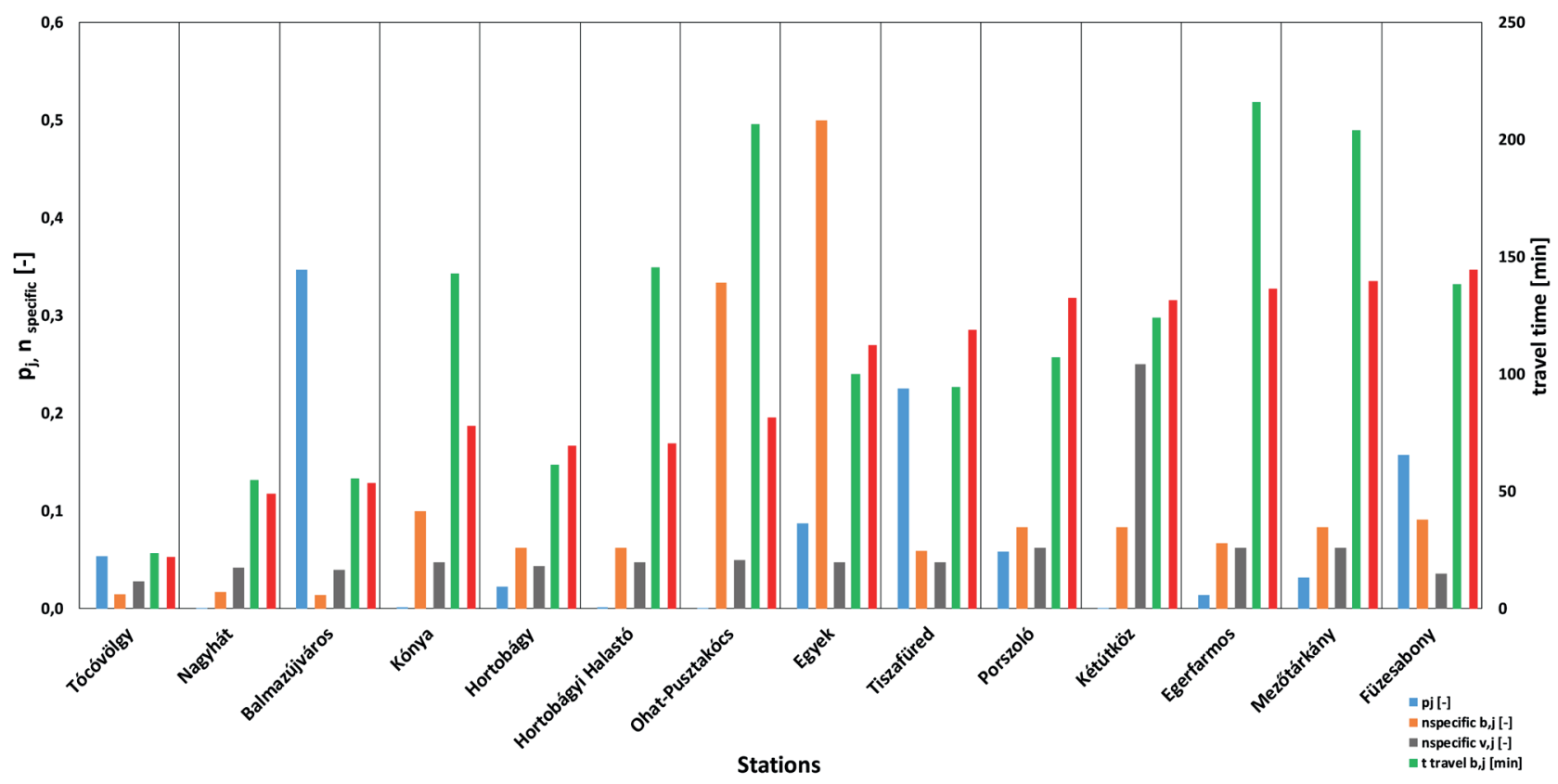

Fig. 9 Calculated values in the link Debrecen-Füzesabony (source: own compilation)

counties - has significantly lower quality index numbers from those for the railway. It is essential to mention that the methodology needs further adjustments, and the data must be correctly interpreted.

The optimization of train stations is probably a necessary and suggested intervention (e.g. Hortobágyi Halastó, Nagyát, Kónya, Kétútköz, Ohat-Pusztakócs, Egerfarmos), thus decreasing the value of access time between Debrecen and other larger cities. In case of the towns mentioned above an on-demand bus transport system is suggested. This on-demand bus could service the train station and other larger hubs as well.

In the course of the analysis, while comparing typical parallel bus and railway links, the value of the link-related quality index number never markedly rise above five. Clearly, this is the case when comparing main railway links and the parallel bus links.

When comparing Hungary's current (2019) regional parallel bus- and railway links and evaluating them with a quality index, it is worth mentioning - and evaluating based on the above example - this problem in other European countries too. For instance, Finland has similar problems.

\section{Analysis and discussion}

Finland's interurban (long-distance) railway passenger transport is operated by state-owned VR Group, also known as VR Yhtymä Oy. This company includes 28 subsidiaries and consists of 3 departments operating around customer groups, such as passenger transport (VR), logistics and freight (VR Transpoint), and track maintenance (VR Track). One major difference from the Hungarian examples that VR Groups owns a bus company (Pohjolan Liikenne Oy), which is one of Finland's biggest autobus passenger transport companies. It needs to be noted that the Nordic country's bus market is liberalized, i.e. besides the state-owned auto bus company, there are several (approximately 84) privately operated auto bus companies too. This is not the case with the railway, as according to a contract regarding passenger transport monopoly between VR Group and the Finnish government, until 2024 only this company is allowed to operate railway passenger transport. The regional (long-distance) railway network in Finland can be described as North-South directed and radiating from Helsinki as the center, with suburban public transport only present in the capital city area. Railway links connect regional capitals and with the capital city. The connection between the centers is supplied primarily by express trains, Intercity trains, and Pendolinos. Apart from a few express trains, local trains almost exclusively serve the smaller towns and farmlands located by the radiating main links. Supporting and secondary links are deficient on the network level. Passenger transport service on the existent links is regularly inspected and, where justified, terminated. There is a good example for this, where authors [16] of the article describe that early 2016 supporting secondary were shut down, and 28 low-traffic railway stations were closed, with an expected 12 million Euro cost reduction by 2020 . 
The primary role of bus links located along the main railway links is to carry passengers to and from the railway i.e. connecting the smaller settlements with the railway, even in a demand-responsive manner. The network is serviced by bus links, so that railway maintenance, development and the higher level of passenger service is concentrated on the main links, while villages, farms and smaller towns are integrated into the transport network by bus links.

Naturally, parallel regional and long-distance public transport exists in Finland too, but the main attraction of the bus links is the differences in the ticket price. On a journey from Tampere to Oulu (about $500 \mathrm{~km}$ ) on a weekday while a train ticket costs 52 Euros, a bus ticket costs 47 Euros. This is the basic fare online discounts are not taken into account. Different kinds of discounts from ticket prices might be available depending on the time of purchase type of transport, or time of travel. For instance, the $58 \mathrm{~km}$ long railway link No. 16 between Parikkala (located in Southern Karelia region) and Savonlinna (situated in Southern Savo region, which is famous for its picturesque lakes) has a bus link running parallel. The results of the analysis are listed in Fig. 10. Originally the mentioned railway link had passenger transport between Savonlinna and Huutokoski too - a section approximately 50 kilometers long - but it was closed in 2011. Nowadays the part is only used for freight transport.

It can be seen from Fig. 10 that trains circulating on this link do stop at minor stations (e.g. Kerimäki, Retretti, Lusto), but these towns generate significant touristic traffic due to the many museums and cultural institutions located there. The bus link shows a high supply value between
Savonlinna and the closest town with a high number of inhabitants (Pääskylahti), which can be explained by the distance between the two cities $(5 \mathrm{~km})$ - i.e. commuting to and from the train by bus is meaningless. Fig. 10 also shows that between Savonlinna and towns with a higher population that are further away supply on the railway is 2-3 times greater than on a bus. Based on Finnish National Public Transport Timetable, it can also be observed that bus supply is available only in the morning and afternoon rush hour, while trains run on a cyclic schedule every 3 hours, adjusted to the timetable of the Helsinki-Joensuu link. Examining the travel time values between the two biggest cities on the link (Savonlinna and Parikkala) railway has much more favorable travel time value (15 minutes less) than the bus, opposed to other bigger towns. It needs to be noted that the railway's desirable travel time values can be guaranteed with a maximum allowed speed of $110 \mathrm{~km} / \mathrm{h}$. Convenient values can be reached due to the station optimization protocol mentioned before. As a result, in the past years three low-traffic stations (Putikko, Kultakivi, Särkisalmi) were closed that served small villages and scattered settlements. Nowadays these locations are served by bus.

The analysis was based on the methodology presented before and received a quality index of 7.57, which is outstanding regarding the comparisons done so far (in Hungary). Based on the Finnish example presented above, and Fig. 2 the quality index of Hungarian regional parallel links is shown before could be improved. The DebrecenFüzesabony link might be reorganized by station optimization with regards to villages, farms, and townships with few inhabitants. This means that on the Debrecen-Füzesabony

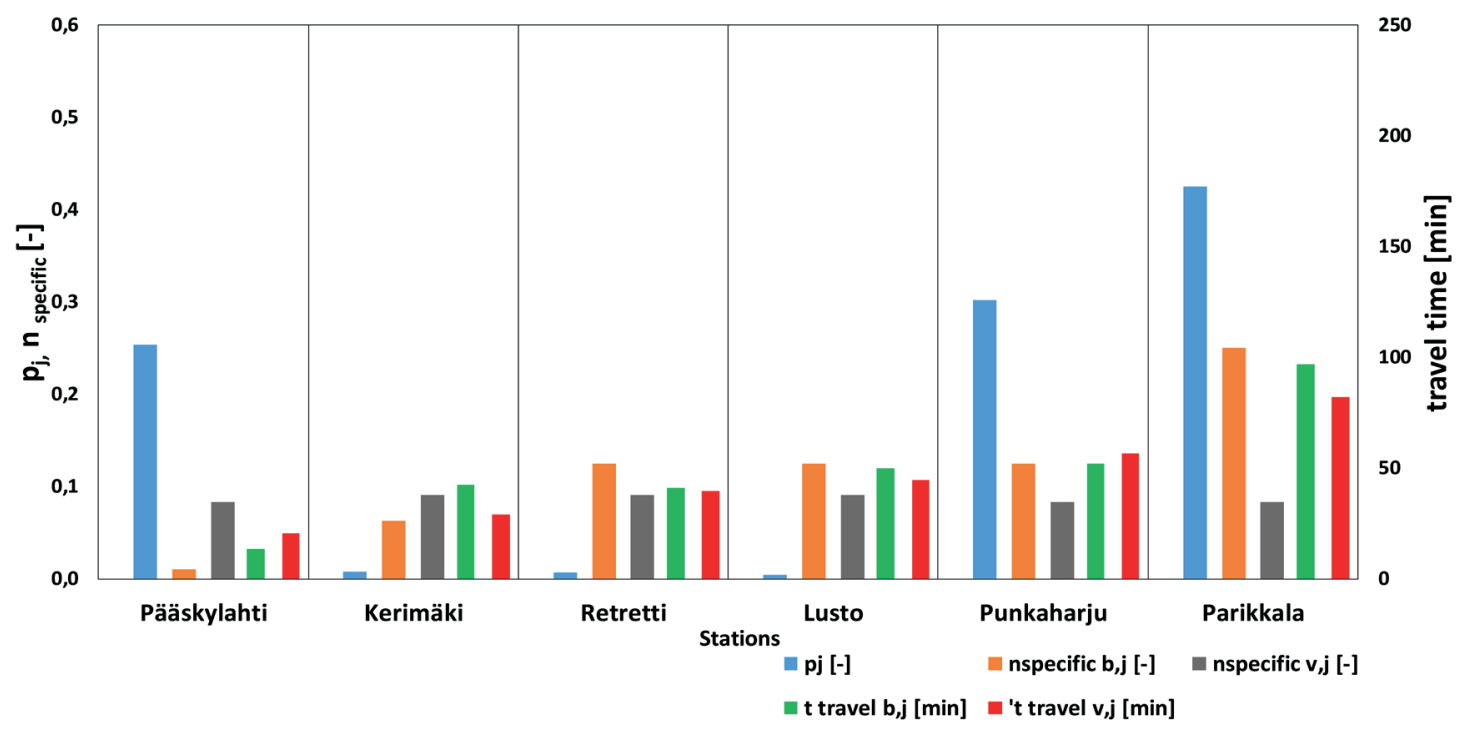

Fig. 10 Values calculated for the Parikkala-Savonlinna link (source: own compilation) 
link trains would skip units with less than 1000 inhabitants putting the closed stations out of commission, replacing the train service with on-demand bus service carrying passengers to and from the closest operational railway station. Based on this, the following railway stations would be closed: Nagyhát, Kónya, Hortobágyi Halastó, Ohat-Pusztakócs, Kétútköz, Egerfarmos. The Hortobágyi Halastó station, to serve tourist traffic, might be operated periodically (e.g. during school breaks in summer). The modified values with 4-minute running time reduction - including passenger changing time and the time diesel vehicles need for braking and accelerating are listed in Fig. 11.

The railway's travel time values are significantly reduced, which increases its competitiveness. Besides this application another solution of the Finnish link's railwayand bus supply is recommended, i.e. the number of railway departures between the starting point and the furthest city is much higher than the number of bus departures. This way the high supply value of bus transport between Debrecen and Tócóvölgy or Balmazújváros remains. Meanwhile between Debrecen and further, more populated towns (e.g. Tiszafüred or Füzesabony) it is necessary to decrease the bus supply and increase the railway supply, for instance by applying a cyclic schedule, like an interregional link, which nowadays has close to similar travel time values. Following the Finnish example, the used values guarantee the $2-3$ bus departures in the morning's and afternoon's rush hours per directions in case of the bus service. With these modifications, the value of the quality index number increases from 5 to 7.80 , which results in a significant increase in the competitiveness without renovating the tracks. With the suggested interventions between Debrecen and the mentioned towns in Fig. 11 the railway capacity could be increased by passengers, while the value of the supply in case of the bus can be decreased by passengers. Based on [15] and calculate with 200 workdays and the vehicles operating in present days (M41 type engine, $2 \mathrm{Bhv}$, and $1 \mathrm{BDt}$ type carriage, as well as diesel buses with 50 passenger capacity), the intervention results in approximately 600 million HUF extra cost per year. Comparing the previous costs to the renovation costs (2.3 billion HUF per kilometers) it can be stated that in some cases the competitiveness of the railway can be increased by transport organization modes. The presented calculation does not contain the operation costs of the demand responsive bus transport system, which serves the closed train stops.

\section{Conclusions}

Competition between parallel bus and railway links in Hungary and Europe is a current problem, as are long term sustainability and efficiency of transport modes. A balanced transport policy would ensure the complementary nature of

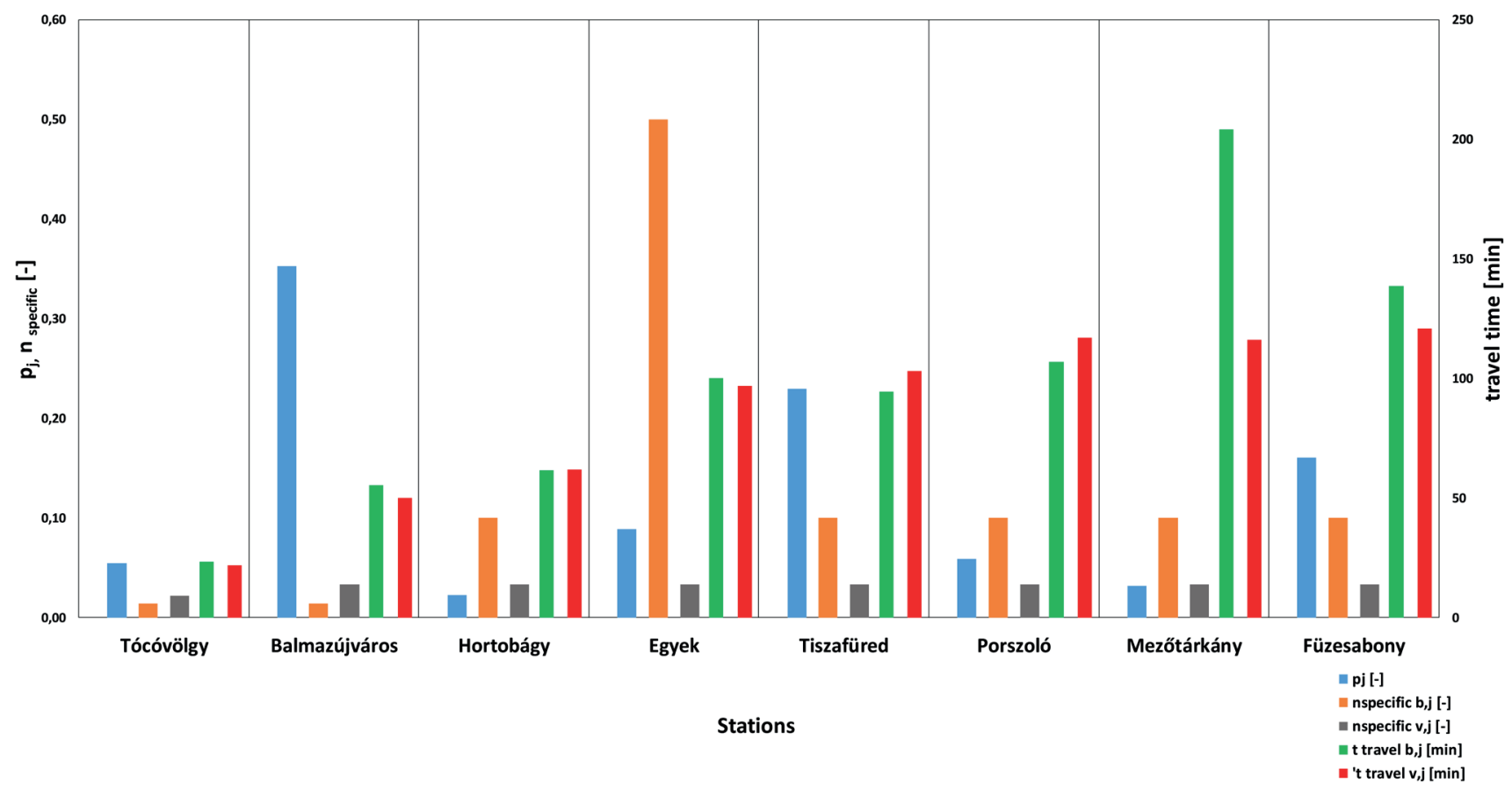

Fig. 11 The values calculated for the link Debrecen-Füzesabony modified by the optimization of the stops and by the Finnish protocol (source: own compilation) 
these subsectors. Parallel bus and railway links are present in our daily lives, which can result in an unsustainable market and distortion in competition. This problem can be solved by optimization of possibilities in parallel public transport. This analysis presents a methodology, which can be applied to investigate the parallels in regional public transport. The procedure is based on four steps.

1. Choosing parallel links. In this research, all 7 Hungarian regions were included with typical links. At least one parallel bus and railway link were examined in each region.

2. Collecting data and building a comprehensive database (travel times, number of departures per day, the number of inhabitants of the settlements covered by the links).

3. Calculating the quality index regarding the parallel bus and railway links, which is based on and derived from the previous data. Based on the calculated values, the following interventions can be suggested for increasing each transport modes' competitiveness.

- If the value of this index number is less than -5 , then the competitiveness of the railway link can be increased only with significant investment (e.g. railway line electrification, replanning the track, increasing the speed etc.) if it is reasonable. If unreasonable (e.g. the value of social benefits is extremely slight), the bus service should be increased;

- If the value above is between -5 and -1 , then the competitiveness of the railway is increasable with transport organization tools (e.g. cyclic schedule,

\section{References}

[1] Farkas, D., Hagymási, G., Nagy, B. "A helyközi közösségi közlekedés jelenlegi helyzetének ismertetése és hazai szervezésének lehetőségei", (Presentation of the current situation of interurban public transport and possibilities for its organization in Hungary) Vezetéstudomány, 5, pp. 26-36, 2010. (in Hungarian) [online] Available at: http://unipub.lib.uni-corvinus.hu/2791/ [Accessed: 22 January 2019]

[2] Ács, B. "A távolsági autóbusz-hálózat múltja, jelene, jövője", (The past, present and future of the long-distance autobus network) KTI Évkönyv, pp. 18-26, 2017. (in Hungarian)

[3] Andrejszki, T., Csete, M., Torok, A. "Identifying modal shift by utility functions to reach an optimal point of regional development", In: Proceedings of the 14th International Conference "Reliability and Statistics in Transportation and Communication" (RelStat'14), Riga, Latvia, 2014, pp. 2-8. [pdf] Available at: http://real.mtak. hu/28255/7/ACsT.pdf [Accessed: 8 February 2019] stop optimization), besides holding the bus service's small towns exploring the role (even the DRT);

- If the value of the index is about 0 (between -1 and 1), besides holding the parallel bus and railway services we should increase the quality of service and revise the transport system (e.g. the different transport modes complementing each other in space and time; the better serving of the demands);

- In the case of values between 1 and 5 the bus links should carry to and from the railway links. Besides this, the revision of the railway stops is needed (creating a direct connection between the regional centers and bigger towns without intermediate stops). The closed railway stops because of the optimization - should be served by demand-responsive bus transport;

- If the value is above 5, then the role of the bus service in the public transport network should be revised (e.g. modifying the bus routes, closing bus links, changing the supply etc.).

4. Introducing the possible innovative interventions, for instance BRT or DRT.

Based on the methodology, many researches can be performed. In the next steps, authors will recalculate the index scores regarding all the parallel links after applying the suggested interventions and examine the mathematical validation of values of quality index number. Furthermore, the application of the methodology in freight transport should be investigated.

[4] Abramović, B., Lovrić, I., Stupalo, V. "Analysis of Intermodal Terminals Service Quality in the Republic of Croatia", Promet Traffic\&Transportation, 24(3), pp. 253-260, 2012. https://doi.org/10.7307/ptt.v24i3.318

[5] Abramovic, B., Zitricky, V., Mesko, P. "Draft Methodology to Specify the Railway Sections Capacity", LOGI-Scientific Journal on Transport and Logistics, 8(1), pp. 1-10, 2017. https://doi.org/10.1515/logi-2017-0001

[6] Abramović, B. "Infrastructure Access Charges", In: Marinov, M. (ed.) Sustainable Rail Transport, Springer, Cham, Switzerland, 2018, pp. 45-58. https://doi.org/10.1007/978-3-319-58643-4_4

[7] Brnjac, N., Abramović, B., Maslarić, M. "Forecasting Intermodal Transport Requirements on Corridor X", Promet Traffic\&Transportation, 22(4), pp. 303-307, 2010. https://doi.org/10.7307/ptt.v22i4.195 
[8] Droździel, P., Rybicka, I., Madleňák, R., Andrusiuk, A., Siłuch, D. "The engine set damage assessment in the public transport vehicles", Advances in Science and Technology Research Journal, 11(1), pp. $117-127,2017$ https://doi.org/10.12913/22998624/66502

[9] Gasparik, J., Mesko, P., Zahumenska, Z. "Methodology for Tendering the Performances in Long Distance Rail Passenger Transport", Periodica Polytechnica Transportation Engineering, 47(1), pp. 19-24, 2019. https://doi.org/10.3311/PPtr.11192

[10] Gašparík, J., Abramović, B., Zitrický, V. "Research on Dependences of Railway Infrastructure Capacity", Tehnički Vjesnik, 25(4), pp. 1190-1195, 2018. https://doi.org/10.17559/tv-20160917192247

[11] Zitrický, V., Černá, L., Abramovič, B. "The Proposal for the Allocation of Capacity for International Railway Transport", Procedia Engineering, 192, pp. 994-999, 2017 https://doi.org/10.1016/j.proeng.2017.06.171

[12] Albert, G., Tóth, Á. "A párhuzamosság, helyettesíthetőség számszerüsítése a közforgalmú közlekedésben", (Quantification of parallelism and substitutability in public transport) Közlekedéstudományi Szemle, 3, pp. 30-35, 2008. (in Hungarian)
[13] Zhu, F., Chen, S., Lv, Y., Ye, P., Xiong, G., Dong, X. "Parallel public transport system and its application in the evacuation of largescale activities", In: Intelligent Transportation Systems (ITSC) 15th International IEEE Conference, Anchorage, AK, USA, 2012, pp. 102-107. https://doi.org/10.1109/ITSC.2012.6338866

[14] Bocz, P., Kisgyörgy, L., Vasvári, G. "Etraffic - an Open Access Transportation Model", Periodica Polytechnica Civil Engineering, 61(3), pp. 564-568, 2016. https://doi.org/10.3311/PPci.9355

[15] Mándoki, P., Lakatos, A. "A magyarországi vasúti és távolsági autóbuszos személyszállítás párhuzamosságának kérdései az utazási paraméterek szempontjából", (Issues of parallelism of Hungarian rail and long-distance bus and coach transport in terms of travel parameters) Közlekedéstudományi Szemle, 67(3), pp. 64-76, 2017. (in Hungarian) https://doi.org/10.24228/KTSZ.2017.3.5

[16] YLE "VR to close nearly 30 train stations, some routes", 2015. [online] Available at: https://yle.fi/uutiset/osasto/news/vr_to_close_ nearly_30_train_stations_some_routes/8307702 [Accessed: 15 December 2018] 